\title{
Utilizing local microorganisms with different dosages and duration of fermentation towards digestibility and rumen activity of oil palm frond in vitro
}

\author{
Randi Mulianda, Ma'ruf Tafsin, Nevy Diana Hanafi*, dan Yulinas \\ Faculty of Agriculture, Universitas Sumatera Utara, Medan20155, Indonesia
}

\begin{abstract}
This research entitles "utilizing local microorganism with different dosages and duration of fermentation process towards digestibility and rumen activity of oil palm frond in vitro" has been done with purpose to know the effect of fermented feed processing technology towards digestion value and fermentability in vitro. The design used in the research was the factorial completely randomized design. The research results showed that the utilization of MOL with can significantly $(\mathrm{P}<0.05)$ improve digestibility and rumen activity in vitro where be indicated by increasing of DMD, OMD, and VFA total, $\mathrm{N}$ ammonia of rumen fluid in vitro, while duration fermentation had no significant effect $(\mathrm{P}>0.05)$ on $\mathrm{OMD}$, and VFA total, $\mathrm{N}$ ammonia of rumen fluid in vitro. Application of MOL at the level $0,6 \%$ with duration of fermentation 7 days show the efficient treatment to increase quality of oil palm frond.
\end{abstract}

\section{Introduction}

The oil palm fronds are by-products of palm fruit harvesting. When it is seen from its availability, palm fronds are very potential to use as animal feed. According to [1], palm pruning cycles are every 14 days, it is about 3 fronds pruned in every cycle, and 1 frond is about $10 \mathrm{~kg}$.

One ha of field is planted about 148 palm trees so that it produces $\pm 4.440 \mathrm{~kg} / \mathrm{ha}$ inevery 14 days or $8.880 \mathrm{~kg} / \mathrm{ha}$ in a month. The content of dry matter in palm fronds is about $35 \%$ so that the total of dry matter in palm fronds is $3.108 \mathrm{~kg} / \mathrm{ha}$ in a month. The analysis results of feed and nutrition science laboratory, Livestock Department faculty of agriculture University Sumatera Utara (2003), the palm fronds contain $6.50 \%$ crude protein, $32.55 \%$ crude fiber, $4.47 \%$ crude fat.

The analysis results show that the content of crude protein in palm fronds is low enough, which is $6.5 \%$ and crude fiber is high enough, which is $32.55 \%$. Low quality feeding with high lignin content will cause rumen condition and function not good enough so that a technology is needed to improve it. Fermentation is a technology to improve feeds origin of waste quality because the involvement of microorganism in degrading the crude

* Correspondingauthor: nevydiana@yahoo.co.id 
fiber, decreasing lignin content and anti-nutritious compounds will increase digestion value of feeds origin of waste [2]. This research objective is to find out utilizing local microorganism with different dosages and duration of fermentation process towards digestibility and rumen activity of oil palm frond in vitro with purpose to know the effect of fermented feed processing technology towards digestion value and fermentability.

\section{Materials and methods}

This research was done in feed and nutrition science laboratory, Animal Science Department, Faculty of Agriculture, University of North Sumatera, Medan. The research was done during three months, started on November until January 2018. In this research, data Analysis used was factorial design (Hanafiah, 2003) with two factors, which were factor A (P) local microorganism (MOL) dosage $(0 \%, 0.2 \%, 0.4 \%$, and $0.6 \%)$ and factor $\mathrm{B}$ (T) duration of fermentation (7,14 and 21 days) and 3 times repetition. Therefore, the total of treatments was $4 \times 3 \times 3=36$ data. The observed parameterswereDry Matter Digestibility (DMD), Organic Matter Digestibility (OMD), and VFA total. Then, the obtained data were measured in form of formula, as follow:

1. Calculation formula of digestibility

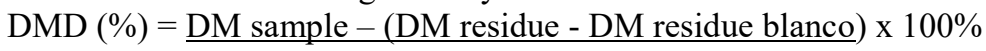

\section{DM sample}

Note: $\mathrm{DMD}=$ digestion ofdry matter

Calculation formula of OMD

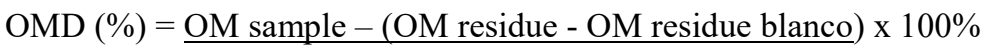

OMsample

[3]

Note: $\mathrm{OMD}=$ digestion of organic matter

2. Rumen activity

Calculation for

VFA total $=(\mathrm{a}-\mathrm{b}) \times \mathrm{N} \mathrm{HCl} \times 1000 / 5 \mathrm{ml}$ (Steam destilation) $(A O A C 1991)$.

Note: VFA Total $=$ volatile fatty acid total

Calculation for $\mathrm{NH} 3$ :

$\mathrm{NH} 3=(\mathrm{ml} \mathrm{H} 2 \mathrm{SO} 4$ titrasi $\mathrm{x} \mathrm{N} \mathrm{H2SO} 4 \times 1000) \mathrm{mM}$ (Owens and Goetsch, 1988)

\section{Measurement proceduresofdry matters digestion coefficient(DMD)}

Residues of centrifugeprocess result were added $50 \mathrm{ml}$ pepsin HCL solution to each fermentor tubes and put into waterbathin temperature $39^{\circ} \mathrm{C}$ for 48 hours. Then, the residues were filtered by using paper filterWhatman no 41 . Every repetition is made Duplo. The filter result was put into oven in temperature $105^{\circ} \mathrm{C}$ for 12 hours. After that, it was chilled in desiccatorsfor 15 minutesand weighed. 


\section{Measurement proceduresoforganic digestion coefficient(OMD)}

OMDmeasurement was done by the way of sample in DMDmeasurement was put into furnace for 6 hours in temperature $105^{\circ} \mathrm{C}$ so that it became ashes. Then, it was chilled in the desiccators for 15 minutes andweighed.

\section{Measurement procedures of VFA Total}

- Five milliliterof supernatant (comes from same tube with supernatantfor analyzing NH3) was put into distillation tube.

- Then, it was added with one $\mathrm{ml}$ of $\mathrm{H} 2 \mathrm{SO} 415 \%$. The tube wall was rinsed by aquadestand covered immediately with rubber cap linked by distillation pipe with \pm $0.5 \mathrm{~cm}$ in diameters.

- After that, the other tip of the pipe was linked to Leibig condenser.

- Next, distillation tube was put into boiling flask contained boiling water without touching its surface.

- Then, distillation result was held by Erlenmeyer flask $500 \mathrm{ml}$ contained by $5 \mathrm{ml}$ $\mathrm{NaOH} 0.5 \mathrm{~N}$.

- The distillation process finished when the holding distillate was $300 \mathrm{ml}$.

- Finally, the holding distillatewas added with phenophtalein (PP) indicator 2-3 drops and titrated with $\mathrm{HCl} 0.5 \mathrm{~N}$ until the color changes from pink until transparent.

\section{Results and discussion}

\subsection{Dry Matters Digestion Coefficient (DMD)}

\section{Table1.Average of DMD (\%)}

\begin{tabular}{|l|c|c|c|c|c|}
\hline \multirow{2}{*}{$\begin{array}{c}\text { Fermentation } \\
\text { (days) }\end{array}$} & \multicolumn{4}{|c|}{ Dosage(\%) } & \multirow{2}{*}{ Average \pm SD } \\
\cline { 2 - 5 } & $\mathbf{0}$ & $\mathbf{0 . 2}$ & $\mathbf{0 . 4}$ & $\mathbf{0 . 6}$ & \\
\hline 7 & $37.64^{\mathrm{Ba}}$ & $40.90^{\mathrm{Ab}}$ & $43.65^{\mathrm{Ac}}$ & $60.10^{\mathrm{Ad}}$ & $45.57 \pm 1.002$ \\
\hline 14 & $39.29^{\mathrm{Ba}}$ & $41.12^{\mathrm{Aa}}$ & $44.57^{\mathrm{Ab}}$ & $61.69^{\mathrm{Ac}}$ & $46.66 \pm 1.114$ \\
\hline 21 & $33.95^{\mathrm{Aa}}$ & $41.83^{\mathrm{Ab}}$ & $45.53^{\mathrm{Ac}}$ & $64.88^{\mathrm{Bd}}$ & $46.54 \pm 0.724$ \\
\hline Average & 36.96 & 41.28 & 44.58 & 62.55 & \\
\hline
\end{tabular}

Description: Superscripts with capital letter to the row showed the significant differences $(\mathrm{P}<0.05)$.

Superscripts with lowercase letter to the column showed the significant differences $(\mathrm{P}<0.05)$.

The result of statistical analysis showed that palm fronds fermented with different dosages and durations of fermentation and the interactions had the significant effect $(\mathrm{P}<$ $0.05)$ towards dry matters digestion level. The highest average of DMDwas in treatment of palm fronds by giving MOL in dosage of $0.6 \% \mathrm{MOL}$, which was $62.55 \%$. The dosage of fermentation of $0.6 \%$ and duration of fermentation in 7 days had affected digestion level in $60.10 \%$.It means that the digestion value of dry matter above is still normal. It is based on [4], who stated that digestion value of dry matter is normal if it is between $50-60 \%$, while according to [5], digestionvalue of dry matter is about 50.63-56.30\%. On the other hand, the lowest percentage of DMD was in treatment of palm frondswas in treatment of palm frond by giving MOL in dosage of $0 \%$, which was36.96\%. 
The result of Duncan test analysis showeed that the highest average of DMD was in treatment of palm fronds with giving MOL in dosage of dosage $0.6 \%$ and duration of fermentation in 21 days was $64.88 \%$. Meanwhile, the lowest average of DMD was in treatment of palm fronds with giving MOL in dosage of $0 \%$ and duration of fermentation in 7 days was 37.64\%. Microorganisms, like Aspergilusniger and Sacharomycescerevisae have degraded palm fronds so that lignin in palm fronds decreases. It is also caused by Aspergilusniger's activities during fermentation produce some enzymes, like cellulase, amylase and catallase that are able to degrade complex compound into the simplest compound so that cells grows. It is in line with [6], who stated that through fermentation, substrate decomposition occurs by some particular enzymes towards indigestive matters, like cellulose and hemicelluloses into simple sugars.

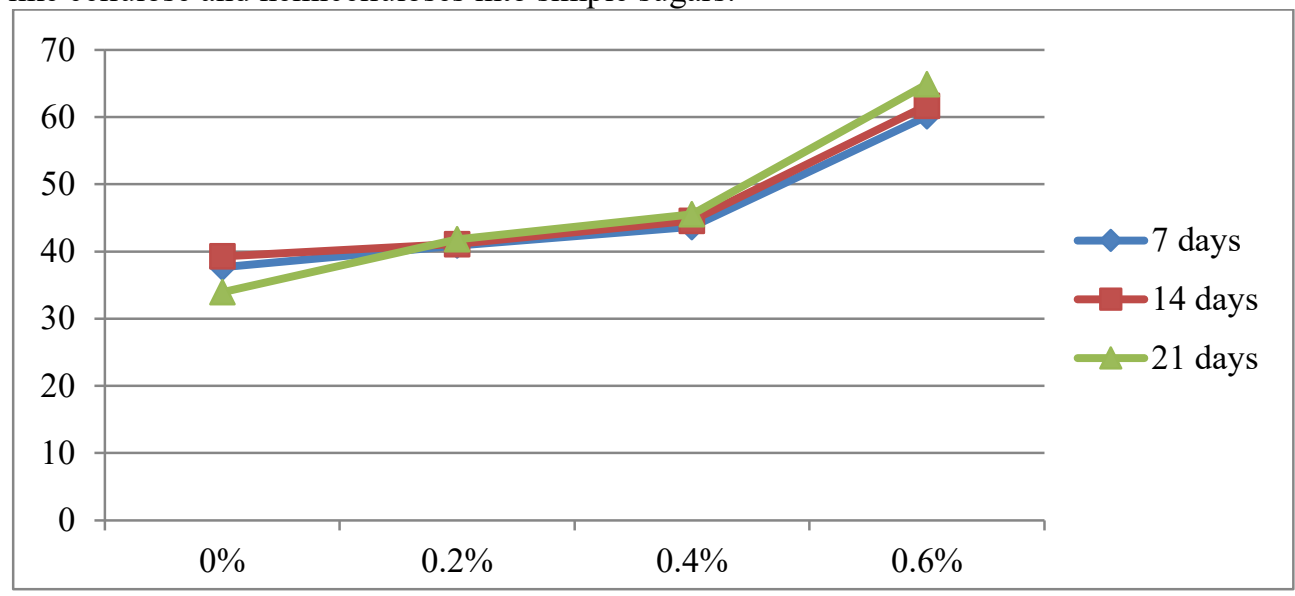

Fig.1. Dry Matters Digestion Coefficient (DMD)

In this research, the fermentation by using MOL is able to increase DMD (Figure 1). It is in line with [7], who stated that something that affects digestibility is feed composition. The feed with complete nutrition composition can improve its digestibility.

[8] reported that palm frond fermentation by using Aspergilus niger, sacharomyces cerevisae and buffalo rumen isolate can increase the DMD 58.86\%. Meanwhile, in this research, the average value of DMD is higher than [8].

\subsection{Organic Digestion Coefficient (OMD)}

Table 2.Average of Organic Digestion Coefficient OMD $(\%)$

\begin{tabular}{|l|c|c|c|c|c|}
\hline \multirow{2}{*}{$\begin{array}{c}\text { Fermentation } \\
\text { (days) }\end{array}$} & \multicolumn{4}{|c|}{ Dosage (\%) } & Average \pm SD \\
\cline { 2 - 5 } & $\mathbf{0}$ & $\mathbf{0 . 2}$ & $\mathbf{0 . 4}$ & $\mathbf{0 . 6}$ & \\
\hline 7 & $36.80^{\mathrm{Ba}}$ & $41.59^{\mathrm{Ab}}$ & $45.74^{\mathrm{Ac}}$ & $59.40^{\mathrm{Ad}}$ & $45.90 \pm 2.216$ \\
\hline 14 & $38.79^{\mathrm{Ba}}$ & $42.05^{\mathrm{Ab}}$ & $44.05^{\mathrm{Ab}}$ & $62.94^{\mathrm{Bc}}$ & $46.95 \pm 1.114$ \\
\hline 21 & $33.03^{\mathrm{Ab}}$ & $42.26^{\mathrm{Ab}}$ & $45.55^{\mathrm{Ac}}$ & $65.78^{\mathrm{Cd}}$ & $46.43 \pm 0.637$ \\
\hline Average & 36.20 & 41.96 & 48.11 & 62.70 & \\
\hline
\end{tabular}

Description: Superscripts with capital letter to the row showed the significant differences $(\mathrm{P}<0.05)$. 
Superscripts with lowercase letter to the column showed the significant differences $(\mathrm{P}<0.05)$.

The result of statistical analysis showed that palm fronds fermented with different dosages and interaction with duration of fermentation gave the significant effect $(\mathrm{P}<0.05)$, how ever duration of fermentation didnot give the significant effect $(\mathrm{P}>0.05)$ towards OMD. The highest average of OMD was in treatment of palm fronds by giving MOL in dosage of $0.6 \%$, which was $62.70 \%$. According [5], OMD of complete feeds is about $48.32-$ $53.75 \%$. In general, the digestion of organic in the treatment of dosage of $0.6 \%$ is still normal, while the lowest percentage of OMD was in treatment of palm frond with giving MOL in dosage of $0 \%$, which was $36.20 \%$.

The result of Duncan test analysis showed that the highest average of OMD was in treatment of palm fronds with giving MOL in dosage of $0.6 \%$ and the duration of fermentation in 21 days was $65.78 \%$, in 14 days was $61.69 \%$, and in 7 days was $60.10 \%$. Meanwhile, the lowest average of OMD was in treatment of palm fronds by giving MOL in dosage of $0 \%$ and the duration of fermentation in 7 days was $36.80 \%$.

[8] reported that fermentation of palm fronds by using Aspergilus niger, Sacharomyces cerevisae and buffalo rumen isolate able to increase OMD $73.88 \%$. In this research, the average value of OMD was $62.43 \%$, which means it was lower than Tafsin et al's. The organic digestion value has similar scheme to the dry digestion value. The organic digestion has higher value than the dry digestion. It is caused by dry matters still contain organic in it, while organic does not contain dry matters. [9] stated that organic digestion value is in line with dry matter digestion value. It is caused by organic is a part of dry matters. The height of organic digestion value is also caused by high composition of crude protein. As a result, the growth of microorganisms which digest the feeds also increases. Graphic 2 below illustrates the organic digestion coefficient (OMD).

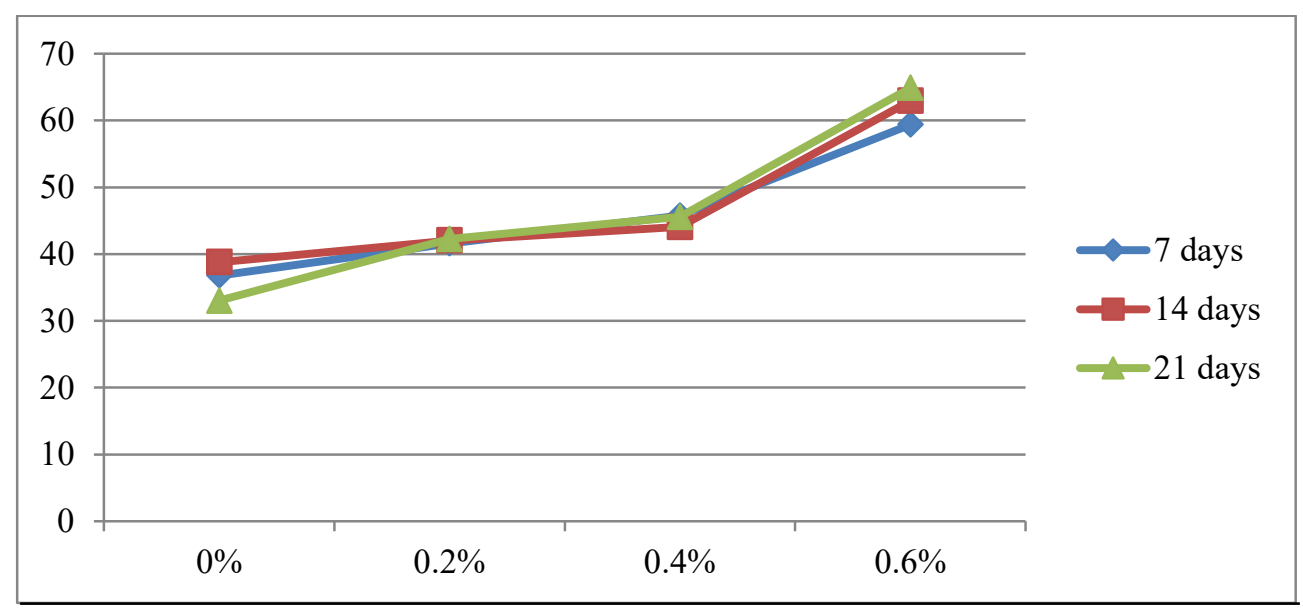

Fig. 2. Graphic of Organic Digestion Coefficient (OMD)

\subsection{VFA Total}

Table 3.Average of VFA Total (mM) Concentration

\begin{tabular}{|c|c|c|c|c|c|}
\hline \multirow{2}{*}{$\begin{array}{c}\text { Durationof } \\
\text { Fermentation }\end{array}$} & \multicolumn{4}{|c|}{ Dosage\% } & \multirow[t]{2}{*}{ Average \pm SD } \\
\hline & 0 & 0.2 & 0.4 & 0.6 & \\
\hline 7 & 68.17 & 80.39 & 93.48 & 111.55 & $88.39 \pm 9.273$ \\
\hline 14 & 68.93 & 87.16 & 103.09 & 114.61 & $93.44 \pm 13.405$ \\
\hline 21 & 71.52 & 91.10 & 110.03 & 122.51 & $98.79 \pm 16.395$ \\
\hline
\end{tabular}


\begin{tabular}{|l|l|l|l|l|}
\hline Average & $69.54^{\mathrm{d}}$ & $86.21^{\mathrm{c}}$ & $102.20^{\mathrm{b}}$ & $116.22^{\mathrm{a}}$ \\
\hline
\end{tabular}

Description: Different superscriptsin the same line show significant differences $(\mathrm{P}<0.05)$

Volatile Fatty Acid (VFA) is a final product of carbohydrate fermentation and rumen origin primary energy source. Beside the VFA, carbohydrate fermentation in rumen produces $\mathrm{CO} 2$ and $\mathrm{CH} 4$ [13].

The result of statistical analysis showed that the oil palm fronds fermented with different dosages gave the significant effect $(\mathrm{P}<0.05)$, however duration of fermentation and their interaction didnot show significant effect $(P<0.05)$ towards VFA total concentration. The highest average of VFA total was in treatment of palm fronds by giving MOL in dosage of $0.6 \%$, which was $116.22 \mathrm{mM}$. The result of Duncan test analysis showed that the highest average of VFA was in treatment dosage of $0.6 \%$ and duration of fermentation in 21 days $(122.51 \mathrm{mM})$. On the other hand, the lowest average of VFA was in treatment of palm fronds by giving MOL in dosage of $0 \%$ and duration of fermentation in 7 days was $68.17 \mathrm{mM}$.

The result of the research showed that there is an increasing of the average of VFA total concentration from $69.54 \mathrm{mM}$ to $116.22 \mathrm{mM}$ with incresing dosage of MOL. According to [10], the normal range of rumen liquid VFA which supports microbes' growth is 80-160 mM. In addition, [11] stated that Aspergillus niger has been known to produce enzymes to degrade fiber. It is supported [12], who stated that Aspergillus niger can produce extracellular enzymes like cellulase, amylase, pectinase, amyloglucosidase, glucoseoxyidase and catalase. The enzyme which affects to the increasing of VFA total concentration of fermentation using Aspergillus niger.

In this research, production of the best VFA total was in range of $111.26-122.53$ mM.It is still above the range of VFA concentration produced by rumen microbes in normal condition, which is $80-160 \mathrm{mM}$ [10]. Besides that, in this research, ammonia concentration was in range of $93.47-122.53 \mathrm{mM}$, which means the concentration still suffices to microbes' needs which is in range of $6.0-17.65 \mathrm{mM}$ [13]

\subsection{Amonia ( $\left.\mathrm{NH}_{3}-\mathrm{N}\right)$}

Table 4.Average of Amonia $\left(\mathrm{NH}_{3}-\mathrm{N}\right)$ Concentration $(\mathrm{mM})$

\begin{tabular}{|l|c|c|c|c|c|}
\hline $\begin{array}{c}\text { Duration of } \\
\text { Fermentation } \\
\text { (days) }\end{array}$ & \multicolumn{4}{|c|}{ Dosage \% } & Average \pm SD \\
\cline { 2 - 5 } & $\mathbf{0}$ & $\mathbf{0 . 2}$ & $\mathbf{0 . 4}$ & $\mathbf{0 . 6}$ & \\
\hline 7 & 5.36 & 6.11 & 6.53 & 6.10 & $6.425 \pm 0.435$ \\
\hline 14 & 5.55 & 6.13 & 6.92 & 7.70 & $6.622 \pm 0.515$ \\
\hline 21 & 5.99 & 6.29 & 7.16 & 7.89 & $6.385 \pm 0.853$ \\
\hline Average & $5.63^{\mathrm{c}}$ & $6.17^{\mathrm{bc}}$ & $6.87^{\mathrm{ab}}$ & $7.23^{\mathrm{a}}$ & \\
\hline
\end{tabular}

Note: Different superscripts in the same row showed significant differences $(\mathrm{P}<0.05)$

The results of the analysis showed that the MOL dosages gave a significant effect $(\mathrm{P}$ $<0.05)$, while the fermentation time and their interaction did not give a significant effect $(\mathrm{P}>0.05)$ on the concentration of ammonia of rumen fluid. The lowest ammonia concentration showed by dosage $0 \%$, while the highest ammonia concentration showed by dosage $0,6 \%$. Increasing dosage of MOL increased the ammonia concentration on rumen fluids. The amount of ammonia produced is still within the normal range of ammonia required for growth of the microbial, optimum NH 3 concentration required to support microbial growth is 4-12 $\mathrm{mM}$ (average $8 \mathrm{mM}$ ). 


\section{Conclusions}

The utilization of MOL with different dosages can improve digestibility and rumen activity in vitro where be indicated by increasing of DMD, OMD, and VFA total, N ammonia of rumen fluid in vitro. Application of $\mathrm{MOL}$ at the level $0,6 \%$ with duration of fermentation 7 days show the efficient treatment to increase quality of oil palm frond.

\section{Acknowledgements}

The author want to say thank to Directorate General of Higher Education for supporting fund through DRPM 2018 for this research.

\section{References}

1 E. Wina, Teknologi Pemanfaatan Mikroorganisme dalam Pakan untuk Meningkatkan Produktivitas Ternak Ruminansia di Indonesia. Sebuah review, Wartazoa 15 (4): 173$186(2005)$

2 J.M.A. Tilley and R.A. Terry, A two stage technique for in the in vitro digestion of forage crops. J. Grassland Soc. 18:108 (1963)

3 T. Sutardi, A.S. Amirroenas, T.D. Jalaludin, Penggunaan Pod Coklat dan Leguminosa Pohon serta Supplementasi Analog Hidroksi Metionin dan Defaunasi Pada Ruminansia. Dipresentasikan dalam Forum Komunikasi Hasil Penelitian Bidang Peternakan di Yogyakarta, 23 - 25 November 1993 (1993)

4 J. Firsoni, A.S. Sulistyo, T. Suharyono. Uji Fermentasi In Vitro terhadap Pengaruh Suplemen Pakan dalam Pakan Komplit. Pusat Aplikasi Teknologi Isotop dan Radiasi BATAN. Fakultas Peternakan Institut Pertanian Bogor.hal :

5 P. Sembiring, Biokonversi Limbah Pabrik Minyak Inti Sawit Dengan Phanerochaete Chrisosporium dan Implikasinya Terhadap Performans Ayam Broiler. Disertasi. UNPAD. Bandung (2006)

6 A.D. Tillman, H. Hartadi, S. Reksohadiprodjo, S. Prawirokusumoand S. Lebdosoekojo. Ilmu Makanan Ternak Dasar (Gadjah Mada University Press, Yogyakarta, 1991)

7 M. Tafsin, In vitro digestibility of oil palm frond treated by local mocroorganism (MOL).IOP Publishing. 10.1088 (1755-1315) (2018)

8 J. Andayani, Evaluasi Kecernaan In Vitro Bahan Kering, Bahan Organik, Protein Kasar Penggunaan Kulit Buah jagung Amoniasi dalam Ransum Ternak Sapi,(Laporan Penelitian. Universitas Jambi. Jambi, 2010)

9 T.M. Enari, Microbial Cellulase, (Applied Science Pub, New York, 1983)

10 F.W. Purwanti, Kualitas Nutrien Onggok yang Difermentasi Aspergillusniger dengan Penambahan Level Urea dan Zeolit yang Berbeda. Institut Pertanian Bogor. Bogor (2012)

11 P. Mc.Donald, R.A. Edwards, J.F.D. Greenhalgh and C.A. Morgan, Animal Nutrition Sixth Edition, (Ashford Colour Press, Gosport, 2002) 